ROCZNIKI TEOLOGICZNE

Tom LXVII, zeszyt $1-2020$

DOI: http://dx.doi.org/10.18290/rt20671-5

REV. DARIUSZ PATER

\title{
THE CHALLENGES OF LIVING IN A SOCIETY FACED BY FAMILIES RAISING CHILDREN WITH VISIBLE AND INVISIBLE DISABILITIES
}

\begin{abstract}
There is not a single, commonly accepted definition of disability. All representatives of science stress that regardless of the kind of disability, it does not only refer to the individual, but also to a relation between the individual and society. A society that accepts the fact that there exist things that are imperceptible to the human eye is more likely to accept various disabilities, also those invisible ones.
\end{abstract}

Key words: disability; visible disability; invisible disability; children's cerebral palsy; depression; suicide.

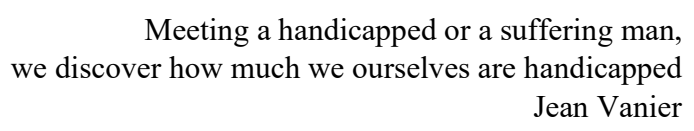

Disability is a term with a legal meaning, which means that the law defines disability and its types, as well as regulates who has the power to certify disability and what are its consequences. But there is also a common understanding of disability. The discrepancies between these two definitions cause some problems in the approach to disability. Not every disability is visible and not every disability justifies a claim for special treatment in the eyes of society. A person walking on crutches is usually treated favorably. Crutches are their disability ID card, although people using them may not have a disability certificate. Generally, society considers this message as sufficient to look after a person with crutches, if only by giving up seats on public transport. Nobody asks about the formal side of their disability. However, it is not only people with visible disabilities who have the right to spe-

Rev. DARIUSZ PATER, Prof. UKSW, Faculty of Theology UKSW in Warsaw, theologian, bioethicist, psycho-oncologist; address for correspondence: 00-213 Warsaw, ul. Bonifraterska 12, pater darek@wp.pl 
cial treatment, but also people whose disability is somehow hidden. Generally, the disabled do not want to reveal their disability because they fear being rejected. However, if they want to enjoy the privileges and benefits they are entitled to, they must prove their disability.

Some mental or internal illnesses do not manifest themselves with obvious physical symptoms. People affected by such illnesses face the dilemma of whether to conceal or reveal their conditions to colleagues. Disclosure may bring some gratification, but requires active identification as a disabled person. The dysfunctions resulting from invisible disability sometimes exclude a person from professional, social and environmental activities. Such a person is often perceived as lazy. However, the situation of a disabled person may be much more complicated than it is seen by society. For example, we should not expect a person suffering from depression to tell everyone about his or her dysfunction. This is sensitive data and disclosure may lead to secondary exclusion, e.g. by employers. People with no visible disabilities, therefore, often face the problem of self-stigma: if you do not identify yourself as a disabled person, you will not receive any benefits. And this is not just a problem of society's maturity to accept disability. It is also a problem for people with disabilities as they often escape into their imaginary world and lose the ability to speak openly about themselves.

\section{DISABILITY: INDIVIDUAL AND SOCIAL PERSPECTIVES}

Assuming that disability is a deviation from the normal functioning of the body, we are aware that it will somehow affect everyone in old age. We are able to accept this kind of disability and even prepare for it, because the human body is constantly aging on biological, psychological and social levels. Internal organs and systems start to work slower, activities become limited, and people participate in social life to a much lesser extent. Despite this, these changes are not seen as disabilities. Old age is a normal stage in life, with a more or less acute course. It is much more difficult to accept a disability that prevents us from performing activities consistent with our professional and social status. This type of disability was initially defined by the World Health Organization (WHO), which differentiated three types of health disorders:

- "impairment - understood as a loss or some abnormality of a body structure or function; 
- disability - understood as a result of impairment, manifesting itself in visible physical limitation or inability to perform an activity in the manner or within the range considered normal for a human being;

- handicap - described as an unfavorable situation of a disabled person, resulting from an impairment or disability that limits or prevents the fulfillment of one or several roles regarded as normal in certain social and cultural conditions". ${ }^{1}$

This classification was long a dominant model despite the opposition of international associations of handicapped people, who considered it too medically-oriented and highlighting deficits, while ignoring the capacities of disabled people. These protests led to the publication of a new classification by WHO. The main emphasis in the new description was put on the complexity of the situation, without focusing only on the psychophysical dysfunctions of people with disabilities. In addition, the social consequences of disability were brought to the fore, ignoring the exaggerated reference to the defect. The concepts of disability and handicap that had existed until then were replaced by the terms activity and participation. The new classification includes the following categories: physical limitations, mental limitations; activity limitations; social participation (participation) restrictions. ${ }^{2}$

From that moment, research began to focus on two opposing conceptual models of disability: a medical and a social model. The medical model views disability as an individual, personal problem, which requires medical care, individual treatment, professional help, and individual adaptation. The social model, on the other hand, sees disability as a social problem and focuses on issues such as: bio-psychosocial integration, social attitudes, human rights, individual and collective responsibility, social activities, social policy and social change. ${ }^{3}$ Over the years, however, the second version of the International Classification of Impairments, Disabilities, and Handicaps ceased to be sufficient as well, since a correlation was found between health and external factors. A new universal approach was presented in the International Classification of Functioning, Disability and Health, the conception of which is based on the following general principles: (1) Health is a basic human right. (2) No human person should be discriminated against because of his or her state of health or functioning. (3) A significant part of the human popula-

\footnotetext{
${ }^{1}$ G. DruŻaŁowsKa, "Niepełosprawność,” in: Encyklopedia Pedagogiczna XXI wieku, vol. 3, ed. T. Pilch (Warsaw: Wydawnictwo Akademickie „Żak,” 2004), 646-647.

${ }^{2}$ F. Wojciechowski, Niepetnosprawność. Rodzina. Dorastanie (Warsaw: Wydawnictwo Akademickie „Żak,” 2007), 32.

${ }^{3}$ Ibidem, 34-35.
} 
tion experience some "disability." (4) Disability is a part of life. (5) Human functioning changes at the bodily, individual and social levels. The right solutions must be found at each of them. ${ }^{4}$

In 1994 the European Disability Forum defined a disabled person as "someone with all their rights, in a situation that disadvantages them due to environmental, economic and social barriers, which they cannot overcome in the same way as other people because of the impairment they have experienced. These barriers are all too often increased by depreciating attitudes from society members." 5

\section{SOCIAL CHALLENGES FACED BY FAMILIES RAISING A CHILD WITH A VISIBLE DISABILITY: THE EXAMPLE OF CEREBRAL PALSY}

Several basic types of disability have been differentiated: physical, intellectual, ${ }^{6}$ single, multiple, visible or invisible disabilities. Of the aforementioned, a physical disability is noticed almost immediately as it is associated with limitations on moving and performing everyday activities, as well as the need for another person's care and intolerable, often chronic pain. An example of a visible physical disability is, among others, cerebral palsy ( $\mathrm{CP}$ paralisys cerebralis infantum). There are multiple types of cerebral palsy depending on neuropathological changes in the brain, however, the most common is the division developed by T. Ingram, who distinguishes:

1. bilateral palsy paralysis (diplegia) - paresis of the lower limbs, paresis of three limbs, paresis of four limbs;

2. hemiplegic palsy (hemiplegia) - left or right;

3. bilateral hemiplegia (hemiplegia bilateralis) - paresis of four limbs;

4. cerebellar syndrome (ataxia) - with unilateral or bilateral predominance;

5. athetoid extrapyramidal syndrome (dyskinesiae), spastic, with tremor and changes in muscle tone - one limb, hemiplegic involving three or four limbs;

6. mixed forms - damage to the pyramid-extrapyramidal system. ${ }^{7}$

\footnotetext{
${ }^{4}$ Ibidem, 37.

${ }^{5}$ M.P. PANEK, Wymiary niepetnosprawności (Gdynia: NOVAE RES Wydawnictwo Innowacyjne, 2012), 10.

${ }^{6}$ More on this topic can be found in: A. MALISZEWSKA, W strone antropologii inkluzywnej: głęboka niepetnosprawność intelektualna a człowieczeństwo (Katowice: Wydawnictwo Uniwersytetu Śląskiego, 2019).

7 J. CzochańSKa, Z. ŁosIowski, "Mózgowe porażenie dziecięce," in: Neurologia dziecięca, ed. J. Czochańska (Warsaw: PZWL, 1985), 330.
} 
According to the latest statistics, of 40-50 thousand children with physical disabilities in Poland over half are patients with CP. The incidence of CP in Poland and worldwide is estimated at 2-3 per mile, which means that it occurs in two, three children for every 1000 born. ${ }^{8}$ Cerebral palsy is "nonprogressive dysfunction in the development of the central nervous system, especially the central motor neurons, arising during pregnancy, childbirth or in the perinatal period." ${ }^{, 9}$ Research confirms that many factors affect the risk of having a baby with CP symptoms. These include: mother's chronic medical conditions, hypoxia, fetal infection, evident developmental disorders, use of toxic drugs and substances, smoking and alcohol consumption during pregnancy, premature delivery, placental abruption, asphyxia, meningitis, and also severe jaundice. ${ }^{10}$ Looking at children and then at adults with $\mathrm{CP}$, the following symptoms can be seen: increased muscle tone, flaccidity, paresis or paralysis, involuntary, uncontrolled movements, balance disorders, clumsiness of movements, trembling limbs. Typical CP disorders are accompanied by comorbid symptoms such as epilepsy, visual, hearing and speech disorders, sensory-motor integration disorders or fragmentary deficits, e.g. abstract thinking disorders. ${ }^{11}$

To illustrate the issues discussed, fragments of an interview with family members and friends of 30-year-old disabled Hanna B. were used.

\section{Ewa (58 years old, friend of the family)}

"I remember the day when Ania and Tomek told us that they would be parents for the second time. They were so happy and full of plans. The pregnancy went well without problems. However, the attending physician recommended a caesarean section due to complications at the first delivery. Unfortunately, life writes its own stories. When Hania decided to come to the world, there was a change of duty in hospital and no one was bothered by Ania's request to make a cc, as recommended by the attending physician. It

\footnotetext{
${ }^{8}$ M. Borkowska, Z. Szwiling, Metoda NDT-Bobath. Poradnik dla rodziców (Warsaw: PZWL, 2015), 91.

${ }^{9}$ R. MichaŁowicz, "Problemy kliniczno-diagnostyczne," in: Mózgowe porażenie dziecięce, ed. R. Michałowicz (Warsaw: PZWL, 2001), 17.

${ }^{10}$ K.J. ZABŁOCKI, Mózgowe porażenie dziecięce $w$ teorii i terapii (Warsaw: Wydawnictwo Akademickie „Żak”, 1998), 25.

${ }^{11}$ See A. BorzĘCKA, "Diagnoza dzieci z mózgowym porażeniem dziecięcym oraz komunikacji alternatywnej i wspomagającej," in: Diagnoza interdyscyplinarna wybrane problemy, ed. J. Skibska (Kraków: Wydawnictwo Impuls, 2017), 253-257.
} 
was only when the child's pulse stopped being felt that they started to act in a hurry. But Hania was born in asphyxia." 12

Asphyxia is hypoxia that causes biochemical and structural changes in the blood, tissues and organs of the fetus and newborn baby as a result of short or long-term oxygen deficiency during pregnancy, childbirth or after childbirth. Hypoxia may cause changes in the structure and functioning of the organs of the newborn, and at a later stage of life lead to disorders in physical, mental and mental (intellectual) development. ${ }^{13}$

Ania (62, mother of Hania)

"The doctors didn't hear what I was telling them. And I saw that there was something wrong with Hania. She did not raise her head, did not follow me, did not catch the rattle, she was too quiet. One of the doctors even accused me of making up the child's sickness. I didn't give up, I went from doctor to doctor and finally came across one who took my fears seriously. The diagnosis paradoxically calmed me down. I already knew what was wrong with Hania. At that moment, the only thing that mattered was where I could find help and how soon Hania would recover. It seemed to me then that cerebral palsy would end once my daughter ceased to be a child. However, months and years passed and despite rehabilitation Hania did not recover. I blamed God, I blamed life. I felt hurt by fate. There were days when I was overwhelmed by black despair or rage. Rage at doctors, physiotherapists, teachers for not being able to help my child. Only when Hania got to school in Helenow did I give up. I think it happened after talking to other mothers of children with CP. These conversations were the best therapy for me. Today I know that we will not escape paralysis, so we have to learn to live with it somehow." 14

\section{Hania (30 years old, a disabled person)}

"I don't like the word "wish." I used to say it all the time, because I thought I would recover, study, that I would achieve something in life. But if you ask, I will answer: I wish only two things: that people would not be afraid of me and that pain would not bother me so much. People are weird. I would make them all read The Little Prince and think about the words: "You can only see with your heart. The most important is invisible to the

\footnotetext{
${ }^{12}$ Author's own interview, unpublished, conducted in December 2018.

${ }^{13}$ See I. DĄBROWSKA-JABŁOŃSKA, Sytuacja szkolna dziecka urodzonego w zamartwicy. Rodzaje zagrożeń i możliwości pomocy (Opole: Wydawnictwo Uniwersytetu Opolskiego, 2002), 15-21.

${ }^{14}$ Author's own interview, unpublished, conducted in December 2018.
} 
eyes." The only thing people can see is my body twisted with disease, but inside - here I am, pretty cool Hania. But who cares. As for the pain, they could finally invent some medicine that cures everything. I don't know how long I can live this way, I don't know." 15

Making a diagnosis has far-reaching consequences for the child's acceptance and loving the child as he or she is. Based on research and observation, A. Twardowski distinguishes four periods that parents of children with disabilities go through.

In the first period parents are in shock, and often experience strong negative emotions such as despair, regret, anxiety, a sense of harm, helplessness, or hopelessness. Many parents break down and their mental balance becomes disorganized.

The second period is characterized by depression and a deep emotional crisis. Conflicts and quarrels between parents increase in the family. Often, the father drifts away from the family into alcohol or work, stops dealing with the child's affairs and eventually leaves the family. It is also possible that the mother, preoccupied with duties and overwhelmed by negative experiences, drifts away from the family too.

In the third period, parents apparently adapt to the situation. However, they still do not accept their child's disability, they use various defense mechanisms, deform reality in accordance with their own desires and irrationally believe that their child will recover. They intensively seek help, change doctors, physiotherapists, turn to healers and, believe in the existence of a "miracle cure."

Finally, the fourth period follows, when parents adapt to the situation in a constructive way. They start to accept their child's disability. Contacts with the child begin to bring them satisfaction, they notice their child's progress and are happy about it. Family life and functioning is focused on helping the disabled child. ${ }^{16}$

\section{Ania (62, mother of Hania)}

"Krzyś turned 10 when I found out I was pregnant. He was enthusiastic because he was the only one in the class who had no siblings. I remember him jumping and shouting: "I will be a brother, I will be a brother!" I think he was stronger than us adults when Hania was diagnosed with CP. Seeing how hard it was to look after Hania, he hugged me and said, "Don't worry mommy, I will never leave Hania alone." Then I realized that my daughter's disability changed the life of our whole family."17

\footnotetext{
${ }^{15}$ Author's own interview, unpublished, conducted in December 2018.

${ }^{16}$ See A. TwardowsKi, "Sytuacja rodzin dzieci niepełnosprawnych," in Dziecko niepetnosprawne w rodzinie, ed. I. Obuchowska (Warsaw: WSiP, 1995), 21-27.

${ }^{17}$ Author's own interview, unpublished, conducted in December 2018.
} 
The appearance of a disabled child in the family brings a number of changes to the family life, the most important of which include:

a) changes in emotional bonds between individual members of the family,

b) changes in emotional relationships,

c) changes in the conditions for the development of healthy children,

d) changes in the family structure,

e) changes in parents' professional life,

f) changes in parents' educational attitudes,

g) changes in the functions performed by the family,

h) changes in the social and cultural life of the family,

i) changes in the family's financial situation. ${ }^{18}$

Both the birth of a sick or disabled child, as well as the appearance of a medical condition or a serious injury during the lifetime and development of a child, can disrupt the parents' upbringing process and change their parental attitudes. It is important to bear in mind that various factors influence this new (different) parental approach and attitudes. What is crucial is the parents' psychological condition, their views on the educational process, their attitude towards disabled people, as well as emotional states and experiences during illness or after an injury.

Krzysztof (41 years old, Hania's brother, entrepreneur)

"I am a classic old-bachelor type. My life focuses on work, computer, TV, occasionally games or going out for a beer with friends. So Mom and Hanka desperately want me to get married. But nothing like that will happen. I just got discouraged from girls. None of my ex-girlfriends understood that in the future, next to a baby stroller, there would be a wheelchair going, that in the pharmacy, apart from nappies for the baby, we would buy diapers for Hanka or that the children would leave one day but Hanka would stay in it. I didn't always think so. Like everyone, I deluded myself that Hanka would recover, but these were fantasies, because she is getting worse. I realized that I would never leave Hanka when my mother was taken to hospital in an ambulance. My father was so scared that he called his grandparents. The three of them stood over her and said, 'So what are we going to do with you now?' Hanka looked at me in such a way that I got crazy. I fought with my father and was close to beating him up real bad. Me and Hanka are one. Forever. Period." 19

\footnotetext{
${ }^{18}$ See E. JANION, Dziecko przewlekle chore w rodzinie (Zielona Góra: Oficyna Wydawnicza Uniwersytetu Zielonogórskiego, 2007), 64-75.

${ }^{19}$ Author's own interview, unpublished, conducted in December 2018.
} 
Siblings of children with disability are often confronted with major emotional problems, behavioral disorders or a feeling of poor family ties. Parents focus their attention primarily on children who need more care. It happens that the problems of a healthy child are neglected by parents and considered insignificant, which leads to conflicts in the family. Having a disabled brother or sister significantly changes the life of healthy siblings because: "it causes some psychological and material strain; directly influences the behavior and daily living conditions of able-bodied siblings; shapes their attitude towards disability and, in the long run, influences also the attitude of the communities to which healthy siblings belong - pupils, students, employees." 20

In turn, parents of a disabled child often suffer from the so-called "burnout syndrome." ${ }^{21}$ It causes a sense of loneliness, being misunderstood, fatigue, evading parental duties, and emotional distance to the child.

\section{Ania (62, mother of Hania)}

"I don't feel sorry for myself. I don't cry ... except for one time. Hania was in junior high school then. One day she came back from school so overjoyed that she asked to turn on the computer and typed that she knew who she would be in the future: a fashion designer. I felt so powerless because I already knew that Hania could not achieve it." 22

Marta (60 years old, retired, Hania's godmother)

"Apparently you have a lot of free time when you retire. Somehow I haven't experienced it yet. My schedule now has more duties than when I was working: looking after our parents three times a week and looking after Hania twice a week. I do it for my sister, because she must have time for herself, to do some shopping, to see a doctor, especially that she has been feeling worse lately. Hypertension, thyroid glaucoma, spine and God knows what else, because she is taking more and more painkillers. Now, when I visit her twice a week, there is no excuse for not going to the doctor. I tell her: Do it for Hania. You must be healthy as long as it is possible. Take my help when I can offer it, because if the parents' health deteriorates, I won't be able to come." 23

${ }^{20}$ See B. MoRACZEWSKA, „Sytuacja rodzinna i społeczna rodzeństwa pełnosprawnego mającego brata lub siostrę z niepełnosprawnością," Seminare (2008), 25: 294.

${ }^{21}$ See A. Maciarz, Macierzyństwo w kontekście zmian spolecznych (Warsaw: Wydawnictwo Akademickie „Żak,” 2004), 38-46.

22 Author's own interview, unpublished, conducted in December 2018.

${ }^{23}$ Author's own interview, unpublished, conducted in December 2018. 
Parents and their disabled children struggle not only with the disease, but also with educational problems (access to education at subsequent stages of education, lower education, often inadequate to the child's capabilities and aspirations) and professional problems (inactivity due to the situation on the labor market). Work is crucial for people with disabilities on economic, social and moral dimensions; it determines the sense and quality of their lives, and is a proof of their social usefulness.

\section{INVISIBLE DISABILITY: THE CHALLENGES OF FAMILIES SUFFERING FROM DEPRESSION}

Two terms are used to define a disability that cannot be seen: hidden or invisible. According to M. Racław and D. Szawarska after C.K. Mathews and N.G. Harrington's the term "hidden" ${ }^{24}$ suggests that disability will become visible if we look for it, while the term "invisible" implies that such disability cannot be seen at all because it does not manifest physically, although it affects one's physical functioning. The concept of hidden/invisible disability includes "both specific learning difficulties (i.e. dyslexia, dysortography, dyscalculia), limitations arising from mental health problems (e.g. depression, anxiety), or cognitive problems (e.g. associated with neurological trauma, Asperger spectrum disorders), but also chronic fatigue syndrome or invisible symptoms of multiple sclerosis or fibromyalgia (i.e. chronic fatigue or chronic pain). ${ }^{25}$

People who live with a person with an invisible disability usually do not notice his or her disability automatically. There are many disabilities and chronic illnesses whose symptoms are not directly visible to others. These include both visual disturbances, organ dysfunctions and mental stress.

Equal participation in society is not at all obvious to people with disabilities, especially to people with invisible disabilities who often experience lack of understanding and prejudice. This is because the symptoms of their disability are not visible and very often their disability is quickly put into question. Consequently, people are less sensitive to their problems and are unwilling to offer help and support.

\footnotetext{
${ }^{24}$ M. RACŁAW, D. SZAWARSKA, "Ukryte/niewidoczne niepełnosprawności a polityka tożsamości i etykietowania w życiu codziennym,” Przegląd Socjologii Jakościowej (2018), 15: 34.

${ }^{25}$ Ibidem.
} 
It should also be noted that in research and debate on the integration and accessibility, people with invisible disabilities and their needs are too often overlooked. Accessibility usually refers to providing ramps or sign language translation. And what about those people who, because of a serious illness or aggressive drug therapy, e.g. chemotherapy, have invisible limitations such as severe fatigue? For them, accessibility, experts say, would mean being able to attend video conferences or team meetings through "virtual classrooms." 26

Regardless of which term we use, the social functioning of people with this type of disability is difficult as, generally, people categorize others according to the "able - disabled" scheme. People who look "healthy" are expected to do more. Their different behavior is, therefore, misunderstood, criticized, stigmatized and, as a result, leads to intolerance. Situations resulting from the disease are seen as a manifestation of laziness, carelessness, slowness in action or other moral flaws. While, in fact, these people cannot perform many social roles because of their hidden / invisible disability; they have limited access to education, labor market and social benefits. They live in constant uncertainty, which aggravates their mental state. Some people decide to disclose their status. "The motives for disclosure vary: the desire to be genuinely oneself, especially when constant hiding leads to stress; building and maintaining bonds; the desire to take advantage of the facilities available or to create social change." 27

One of the most common hidden / invisible disabilities is depression. Commonly, the term depression is used to refer to apathy, depressive mood, regardless of the reasons for this condition. In psychiatry, the term depression describes a particular type of mood and emotion disorder. "Depression is defined as a mood disorder characterized by the inability to feel joy, decreased activity, sadness and similar symptoms. Each of these emotions is extreme and intensive and points to various types of depressive disorders." 28 Depression is the result of the interaction of various factors - both psychological and biological. Biological factors include genetic predispositions,

\footnotetext{
${ }^{26}$ See C. Tillmann, Niemand sollte vor seinem Tod sterben. Ein Mutmachbuch für Schwerkranke und ihre Angehörigen (Marburg, 2019).

${ }^{27}$ Ibidem, 41.

${ }^{28}$ B. LELONEK, G. WIRASZKA, "Depresja - współczesny problem zdrowia psychicznego i zagrożenie cywilizacji," in: Wybrane choroby cywilizacyjne XXI wieku, ed. K. Kowalczuk, E. Krajewska-Kułak, M. Cybulski, vol. 2 (Białystok, 2016), 16. For more on this topic see: M. KosowSKA, Depresja w aspekcie teologiczno-moralnym (Kraków: Wydawnictwo Naukowe Uniwersytetu Papieskiego Jana Pawła II, 2015).
} 
changes in the level of neurotransmitters and hormonal systems as well as changes in specific areas of the brain, while psychological factors are, among others, anger towards self, dependence of one's self-esteem on others and helplessness in achieving the goal. ${ }^{29}$ Psychiatrist Aaron Beck identified two types of people who are particularly vulnerable to depression. The first type includes people who excessively care for relationships with others and painfully feel the rejection or loss of these contacts. The second type of people are people with a high level of autonomy, strongly focused on achieving goals, overly critical of themselves and very sensitive to failure. ${ }^{30}$ Feeling of low self-esteem and hopelessness are accompanied by suicidal thoughts and aspirations.

Ania (62, mother of Hania)

"My husband did not manage his daughter's disability emotionally. I didn't notice it at the right time. Not that I didn't want to. The 24-hour care of Hania was so exhausting that I hardly paid attention to anything else. The division of duties seemed obvious to me: my husband was supporting the family and I was running a house and looking after my daughter. This life plan, however, didn't include Krzyś and Tomek. We paid a great price for this: Tomek committed suicide. The words from his farewell letter are not only written deep in my heart, but appear in hard times and hurt, hurt, hurt so much... Saying goodbye, Tom wrote that he felt alone, cheated, that it was not supposed to be like that." 11

Depression carries a significant risk of suicide. The risk of suicidal death among people with mood disorders is $15 \%$. Almost $40 \%$ of people who committed suicide clearly stated their intentions prior to death, and $30 \%$ talked about death several months before committing suicide. Indirect signals took the form of allusions like "it would be better if I were dead" or "if we see each other again." These allusions were both a warning and a call for help, an expression of despair and an ambivalent attitude to death. The analysis of suicide farewell letters indicates that they are usually addressed to relatives or friends. They are generally legible and logically coherent and express positive, negative, neutral and mixed emotions. These letters are sent

\footnotetext{
${ }^{29}$ See M.E.P. Seligman, E.F. Walker, D.L. Rosenhan, Psychopatologia (Poznań: Wydawnictwo Zysk i S-ka, 2003), 284-290.

${ }^{30}$ See R.C. Carson, J.N. Butcher, S. MineKa, Psychologia zaburzeń, vol. 1 (Gdańsk: GWP, 2011), 357-358.

${ }^{31}$ Author's own interview, unpublished, conducted in December 2018.
} 
by post or found by the victim near the place of suicide. ${ }^{32}$ E.S. Shneidman, a recognized and leading researcher of suicide, wrote: "Suicide is almost always caused by pain, a certain type of pain - a psychological pain or "psychache" ... and suicidal death is an escape from it. Pain is the strongest signal in nature, it warns us, mobilizes us and exhausts our strength; pain by its very nature makes us want to get rid of it or to escape from it. Mental pain is a painful wound, a suffering overwhelming the mind, an inseparable part of our psyche, the pain of excessively felt shame, guilt, anxiety, fear and loneliness or the fear of old age and heavy dying. We commit suicide when psychological pain becomes unbearable and forces us to actively seek death as a means of stopping an uninterrupted stream of painful consciousness. Suicide is a drama in the mind." 33

\section{CONCLUSION}

The discussion on disability is very often limited to medical or bioethical issues only. However, a more holistic perspective should be taken that includes a theological reflection as well. Dealing with people with disabilities is not only a medical problem in our society. For example, it should be clarified that disability cannot be bound by a rigid legal framework, but understood from individual and social perspectives. Disability means exclusion from normal social life as a result of physical or mental limitations. Unfortunately, this exclusion often takes place in the Church. This is why the Church needs to organize its own pastoral care of the disabled so that people with disabilities are not excluded.

Dilemmas about disability are not easy to solve. It seems that a good basis for improving the situation of disabled people is precisely maturity and acceptance: a disabled person accepting himself or herself with his or her disability functions much better than a person distorting and falsifying reality. A society that accepts the fact that there exist things that are imperceptible to the human eye is more likely to accept various disabilities, also those invisible ones.

In the encyclical Spe Salvi, Pope Benedict XVI states that "we must do whatever we can to reduce suffering: to avoid as far as possible the suffering of the innocent; to soothe pain; to give assistance in overcoming mental suf-

\footnotetext{
${ }^{32}$ See R.C. CARson, J.N. Butcher, S. MineKa, Psychologia zaburzeń, vol. 1, 394-400.

${ }^{33}$ Ibidem, 390.
} 
fering." 34 Medicine alone can do a lot in this matter, as John Paul II wrote in Salvifici doloris, "the field of human suffering is much wider, more varied, and multi-dimensional." Therefore, human suffering will involve both physical, mental and moral pain, and will affect the depth of humanity. ${ }^{35}$ It will be present more where there is no faith that man is good by nature, that he can love and hope, often against hope, despite the many disabilities he experiences in life. A British disabled artist and motivational speaker Henry Fraser states that "life can be easier and happier when people focus on what they can do for themselves and others instead of what they can't. Every day is a good day." ${ }^{36}$ Maybe it is worth thinking about it?

\section{REFERENCES}

Bedirhan, T. Międzynarodowa klasyfikacja uszkodzeń, aktywności i uczestnictwa ICIDH-2. Warsaw, 1998.

BENEDict XVI. Encyklika Spe salvi. Vatican, 2007.

Borkowska, M., SzWiLIng, Z. Metoda NDT-Bobath. Poradnik dla rodziców. Warsaw: PZWL, 2015.

BorzĘCKA, A. "Diagnoza dzieci z mózgowym porażeniem dziecięcym oraz komunikacji alternatywnej i wspomagającej.” In: Diagnoza interdyscyplinarna wybrane problemy. Ed. J. Skibska, 253-271. Kraków: Wydawnictwo Impuls, 2017.

Carson, R.C., Butcher, J.N., Mineka, S. Psychologia zaburzeń. Vol. 1. Gdańsk: GWP, 2011.

Czochańska, J., Łosıowski, Z. “Mózgowe porażenie dziecięce.” In: Neurologia dziecięca. Ed. J. Czochańska, 328-346. Warsaw: PZWL, 1985.

DĄBROWSKA-JABŁOŃSKA, I. Sytuacja szkolna dziecka urodzonego w zamartwicy. Rodzaje zagrożeń i możliwości pomocy. Opole: Wydawnictwo Uniwersytetu Opolskiego, 2002.

DruŻaŁowska, G. "Niepełosprawność." In: Encyklopedia Pedagogiczna XXI wieku. Vol. 3. Ed. T. Pilch. Warsaw: Wydawnictwo Akademickie „Żak”, 2004.

Fraser, H. Małe wielkie rzeczy. Trans. J. Hardukiewicz-Chojnowska. Kraków, 2018.

John PAUl II, An apostolic letter Salvifici doloris. Vatican, 1984.

JANION, E. Dziecko przewlekle chore w rodzinie. Zielona Góra: Oficyna Wydawnicza Uniwersytetu Zielonogórskiego, 2007.

Kosowska, M. Depresja w aspekcie teologiczno-moralnym. Kraków: Wydawnictwo Naukowe Uniwersytetu Papieskiego Jana Pawła II, 2015.

LELONEK, B., WirASZKA, G. "Depresja - współczesny problem zdrowia psychicznego i zagrożenie cywilizacji." In: Wybrane choroby cywilizacyjne XXI wieku. Ed. K. Kowalczuk, E. Krajewska-Kułak, M. Cybulski, Vol. 2, 16-31. Bialystok, 2016.

\footnotetext{
${ }^{34}$ Benedict XVI, Spe salvi, Vatican 2007, no. 36.

${ }^{35}$ John PAUl II, Salvifici doloris, Vatican 1984, no. 5.

${ }^{36}$ H. FrASER, Mate wielkie rzeczy, trans. J. Hardukiewicz-Chojnowska (Kraków, 2018), 168.
} 
Maciarz, A. Macierzyństwo w kontekście zmian spolecznych. Warsaw: Wydawnictwo Akademickie „Żak”, 2004.

MALISZEWSKA, A. W stronę antropologii inkluzywnej: głęboka niepetnosprawność intelektualna a człowieczeństwo. Katowice: Wydawnictwo Uniwersytetu Śląskiego, 2019.

Michałowicz, R. "Problemy kliniczno-diagnostyczne.” In: Mózgowe porażenie dziecięce. Ed. R. Michałowicz, 15-202. Warsaw: PZWL, 2001.

MorACZEWSKA, B. "Sytuacja rodzinna i społeczna rodzeństwa pełnosprawnego mającego brata lub siostrę z niepełnosprawnością.” Seminare (2008), 25: 294-299.

PANEK, M.P. Wymiary niepetnosprawności. Gdynia: NOVAE RES Wydawnictwo Innowacyjne, 2012.

RACŁAw, M., SzAWARSKA, D. "Ukryte/ niewidoczne niepełnosprawności a polityka tożsamości i etykietowania w życiu codziennym.” Przegląd Socjologii Jakościowej (2018), 15: 30-46.

Seligman, M.E.P., Walker, E.F., Rosenhan, D.L. Psychopatologia. Poznań: Wydawnictwo Zysk i S-ka, 2003.

Tillmann, C. Niemand sollte vor seinem Tod sterben. Ein Mutmachbuch für Schwerkranke und ihre Angehörigen. Marburg, 2019.

Twardowski, A. "Sytuacja rodzin dzieci niepełnosprawnych." In: Dziecko niepetnosprawne w rodzinie, 18-54. Ed. I. Obuchowska. Warsaw: WSiP, 1995.

Wojciechowski, F. Niepetnosprawność. Rodzina. Dorastanie. Warsaw: Wydawnictwo Akademickie ,Żak”, 2007.

ZABŁoCKI, K.J. Mózgowe porażenie dziecięce w teorii i terapii. Warsaw: Wydawnictwo Akademickie „Żak”, 1998.

\section{TRUDNOŚCI W FUNKCJONOWANIU W SPOŁECZEŃSTWIE RODZIN Z NIEPEŁNOSPRAWNOŚCIĄ WIDOCZNĄ I NIEWIDOCZNĄ}

\section{STRESZCZENIE}

Nie istnieje jedna, powszechnie uznana definicja niepełnosprawności. Wszyscy przedstawiciele nauki podkreślają, że niezależnie od rodzaju niepełnosprawności jest ona problemem społecznym, nie ogranicza się tylko do konkretnej osoby, ale dotyczy relacji między człowiekiem a społeczeństwem i środowiskiem, które go otacza. Społeczeństwo, które umie akceptować fakt, że istnieje nie tylko to, co widać, łatwiej przyjmuje różne, nie tylko ewidentne, niepełnosprawności.

Słowa kluczowe: niepełnosprawność; niepełnosprawność widoczna; niepełnosprawność niewidoczna; dziecięce porażenie mózgowe; depresja; samobójstwo. 